\title{
RESPONSE OF THREE ONION (Allium cepa L.) CULTIVARS GROWN UNDER IRRIGATED AND NON-IRRIGATED CULTIVATION TO POLYETHYLENE MULCHING 3- PRODUCTION OF DRY ONION BULBS IN SPRING SEASON*
}

\author{
Caser G. Abdel \\ Amer A. Al-Juboori
}

Horticulture Department, Agriculture \& Forestry College, Mosul Univ., IRAQ

\begin{abstract}
This experiment was carried out at horticultural research fields, Mosul University, Mosul, Iraq, during 2004-2005 growing season to investigate the influences of polyethylene mulching, supplementary irrigation and rainfall incidences on the production of dry bulbs of three onion cultivars grown in spring seasons. Results showed that supplementary irrigated onions resulted in significant increases, bulb fresh weight, bulb size, bulb bulk density, number of storage leaves per bulb, leaf water potential and yield of dry onion bulbs, as compared to these of rainfalls onions. However, inadequate rainfalls tended to reveal significant increases in percentage of unbolted plants and bulbing ratio. Production of dry onion bulbs on bare soil under rainfall incidences in Mosul are impossible in spring season. Polyethylene mulching substantially improved growth and yield of onions, particularly these grown under rainfalls. They confirmed the ability of producing dry yield of onions under rainfalls in spring season. Clear polyethylene mulching appeared to be the most effective treatment, as it displayed significant increases in bulb size, single bulb fresh weight, plant height, leaf numbers per plant, leaf area index, bulbing ratio, dry matter percentage of storage leaf, plant dry weight, leaf area per plant and dry yield of onion bulbs. Moreover, it significantly lessen the water requirements and weed eradication labor cost. Local Red was the paramount cultivar. It showed the highest responses to supplemental irrigation, rainfalls and polyethylene mulching, Since it gave the highest, bulb fresh weight, percentage of unbolted plants and the yield of dry onions. Furthermore, it resulted in the lowest stalk numbers per plant, leaf water potential, fresh and dry weights of flowering stalks. On the other hand Local White cultivar displayed controversial results. The highest yield $\left(1.07 \mathrm{~kg}^{-1}\right)$ was confined to supplementary irrigated Local Red cultivar grown on clear polyethylene mulched soil.
\end{abstract}

\section{INTRODUCTION}

From Iraqi meteorological data, we may inferred that the ambient environment is very suitable for raising mild onions. Demands for onion of mild pungency are increasing around the world. The value of mild onion produced annually in United State and Europe for market exceeds \$ 100 million (Vavrina and Smittle, 1993). Irrigation efficiency would be increased if the water were applied and kept at rate needed by the crop to achieve the desired yield (Al-Jamal, et al., 1999). Shallow rooted crops such as onions are generally more difficult to irrigate and have lower irrigation efficiency values than deep rooted crops. 
*This Project was financed by AHEAD, Hawaii, Mosul and Dohouk Universities Partnerships.

Received 8/12/2005 Accepted 31/5/2006.

The irrigation efficiencies obtained for onion fields ranged from $45-77 \%$, the $45 \%$ represent the non-stressed treatments, in which an extra amount of irrigation above the evapotranspiration requirement was applied to keep the base of onion plates wet ( Al-Jamal et al., 2001 ). Mulching soils by polyethylene was recommended to sustain better moisture, nutrition and temperature at crops root zone ( Clark et al., 1996 and Paris et al., 1998 ). Therefore an attempt was made to mitigate the adverse effects of water scarcity on three local onion cultivars through growing them on soils of different polyethylene mulches.

\section{MATERIALS AND METHODS}

This study was conducted at research fields of Horticulture Department, Mosul University, Mosul, Iraq, during 2004-2005 spring growing season to investigate the influences of polyethylene mulching on the production of dry bulb yield of three irrigated and non-irrigated local onion cultivars.

A Split Split Plot within Factorial-Randomized Complete Block Design ( Split Split F-RCBD) trail was used. The main plots were supplemental irrigation (A1) and rainfall incidences (A2). The sub plots were un mulched soil (B1), clear polyethylene mulched soil (B2) and black polyethylene mulched soil(B3). Whereas, the sub sub plots were Bashiqi cultivar (C1), Local Red cultivar (C2) and Local White cultivar (C3). Therefore, each experiment contained 18 treatments and each was replicated 3 times. Each replicate was represented by a furrow $(0.75 * 5 \mathrm{~m})$ planted on both sides with $15 \mathrm{~cm}$ intra plant space.

Experimental soil was clay, it contained $56.4 \%$ clay, 31.3 silt and 12.3 sand. It possesses field capacity, wilting point and bulk density of $21.8 \%$, $12.9 \%$ and 1.6 g.cm-3, respectively. The soil was plowed twice, dissected to furrows ,one gypsum block was settled at $25 \mathrm{~cm}$ depth from the top of each furrow to truck soil moisture fluctuations throughout the growing seasons (Greenwood, 1982 and Sanders, 1997), then NPK fertilizer was broadcasted at rate of 30 g.m-2, thereafter mulching sub plots were covered by either clear or black poly ethylene. Two slits $2 \mathrm{~m}$ apart were cut in the polyethylene at the bottom of each furrow to facilitate rainfall seepages to furrows, then soil was placed on slits and on outermost polyethylene edges in plots to reduce soil evaporation and to fix the polyethylene. Holes of $15 \mathrm{~cm}$ apart were made on the upper third of each furrow by fork like steel bar of two teeth . Bulb sets of 1-1.5 $\mathrm{g}$ and diameters of 1-2 $\mathrm{cm}$ were sown through the holes and on furrows of bare soil treatments on February, 19, 2005 for spring season.

Supplemental watering was applied whenever $50 \%$ depletion of soil available water capacity is recorded by gypsum blocks. Subsequently, onion plants required 2, 2, 2 and 3 irrigation times for bare soil treatments, respectively, during March, April, May and June. Whereas, polyethylene 
mulched soil required one irrigation time during either March, April, May and June (Table 1 and Figure 1). Supplementary irrigation was ceased 2 weeks before harvesting to prevent the resumption of new leaf differentiations and to confirm the inducement of bud dormancies (Kelley and Granberry, 2000). Polyethylene was torn to ventilate bulbs in order to reduce risks of overheating and fungus infection incidences.

Weeds were manually eradicated during both growing seasons and a protective spay of benomyl fungicide at rate of $1 \mathrm{~g} . \mathrm{l}^{-1}$ was applied on March, 15 , 2005. Rate of 30 g.m-2 of NPK fertilizer was broadcasted again on April, $1^{\text {st }}$, 2005. Finally, plants were harvested on July,12, 2005. Plants were tied and hanged for one week on tree branches to cure them (Greer and Kuepper, 1999).

Data on plant height, leaf numbers per plant, numbers of storage leaves per bulb, bulb doubling percentage, percentage of unbolted plants, number of roots per plant, flowering stalk numbers per plant, leaf length and leaf width were recorded. Leaf area and leaf area index were calculated (Wien, 1997 and Faysal, 1999). Flowering stalks, fresh bulb fresh root, samples of storage leaves , onion plants and onion dry bulbs were weighed to record their fresh weights then oven dried at $65 \mathrm{c}^{\mathrm{o}}$ for $72 \mathrm{~h}$. to obtain their dry weights. Bulb size was measured by water replacement, bulb bulk density was calculated from the weight and volume of individual bulb, hand refrectometer was used to measure total soluble solids of the storage leaves. Leaf water potential and leaf water saturation deficit were measured and calculated as recommended by Abdel (1982) and Spomer (1985).

\section{RESULTS AND DISCUSSION}

Supplemental watering treatments significantly increased plant height $(11.7 \%)$, leaf numbers per plant (14\%), leaf area per plant $(63.4 \%)$, leaf area index $(20 \%)$, percentage of unbolted plants $(26.6 \%)$, bulbing ratio $(4.2 \%)$, bulb bulk density $(3.3 \%)$, number of storage leaves per plant $(9.6 \%)$, dry matter percentage of storage leaf $(10.1 \%)$, plant dry weights $(67.4 \%)$ and dry bulb yield $(49.9 \%)$. However, it showed bulb doubling percentage increases of (43.6\%), as compared to rainfalls treatments (Table,2a). Onions planted in spring season suffered drought from the early growth stages and continued to the end of the season. Thus drastic growth and yield reductions were observed in both irrigated and non-irrigated cultivations in relation to these of fall season in previous experiment. The gap between irrigated and rain fed onions was apparent in this season. Similar results were found in the last season (AlJuboori, 2005), however, he reported much less reductions in relation to our results owing to the higher incidence of rain falls in the previous season. Yield of supplementary irrigated onion of this study was also lower than that reported by Al-Juboori (2005). It seems that rainfalls not only sustain acceptable soil moisture at root zone, but it may provides optimal environments at plant canopies and beyond for instance, decreasing temperature and raising relative humidity which ultimately ameliorate evapotranspiration tendency in very subtle way. Moreover, rainfall may possesses organic and inorganic nutrients in 
favor of growth absorb directly by foliage, especially when such nutrients are not available in the given soil. Reductions in plant growth and yield caused by water stress were aggravated as drought synchronized with bulb formation stage. Very close results were reported by Mississippi (2002). A number of gaseous sulfur and nitrogen compounds, especially $\mathrm{CO} 2$ and $\mathrm{NO} 2$, are emitted into atmosphere through natural processes and/or by mans activities. These gaseous compounds are dissolved in rains, comes down to earth and are added to soil. A study in Alberta (Lau and Das, 1985) showed that about $8.8 \mathrm{~kg}$. ha ${ }^{-1}$ of sulfate, $4 \mathrm{~kg} \cdot \mathrm{h}^{-1}$ of nitrate, and $0.15 \mathrm{~kg} \cdot \mathrm{h}^{-1}$ of hydrogen were added annually to the soil. Shock et al. (1998) stated that most onion roots are occurred at 0 to $25 \mathrm{~cm}$ depth. Severe drought is usually accompanied by root desiccation and death. Rapid death of onion roots were reported by Stasoviski and Peterson (1992), when onion subjected to drought episode of 35 days and prolongation of this episode to 200 days resulted in complete root death. Those results explained the reductions of root numbers per plant and root dry weight observed in non-irrigated treatments of bare soil. Plant height reductions emerged from the accumulative reductions imposed by drought episodes on the performance of both blade and bladeless leaves in which they represent the real plant height ,since contracted stem possesses ignorable contribution to plant height. Reductions in leaf numbers per plant, leaf area per plant, leaf area index, bulb performance and their adverse effects on marketable yield are well established.

Onion grown on polyethylene mulched soil displayed significant growth and yield improvements, particularly with clear polyethylene mulching as it showed substantial increases when it compared to un-mulched treatments, in term of plant height $(55 \%)$, leaf numbers per plant $(22 \%)$, leaf area per plant $(19 \%)$, bulbing ratio $(31.6 \%)$, weight of individual bulb (76\%), bulb size $(74.7 \%)$ and dry bulb yield (47.6\%). Regardless bulb doubling percentage increases $(22 \%)$. Black polyethylene is very effective in weed eradication. It devoid the germinated weed seeds from sun light, creating weak etiolated seedlings creeping under it humid inner surface, making them vulnerable to death. The same fate will be faced under clear polyethylene. Onion is unlike other vegetable crops, it possesses a poor competition capacity to weeds, particularly in the early growth stages, owing to its slow rate of growth, which is nearly equal to half of the growth rate of lettuce and cabbage (Brewester, 1979). Polyethylene mulching were found to reduce the infection incidences by virus (Singh, 1992), wilting verticillium dahliae (Stapleton,1993) and soil borne diseases (Strek et al. 1996). However, the cost of polyethylene is questioned and the justifications of its application depend upon the area, water availability, weed eradication cost which should be compromised economically by producers.

Local Red seemed to be the most responded cultivar in most detected parameters. It gave substantial increases in plant height $(38.9 \%)$, leaf numbers per plant $(20.9 \%)$, leaf area per plant (110.7\%), leaf area index $(217.5 \%)$, percentage of unbolted plants $(153.7 \%)$, bulb fresh weight $(34.4 \%)$, bulb size $(37.2 \%)$, storage leaf numbers per bulb $(8.3 \%)$, dry weight of plants $(74.2 \%)$ 
and dry bulb yield (54.6\%). Furthermore it significantly exceeded Bashiqi cultivar in plant height $(14 \%)$, leaf numbers per plant $(20.9 \%)$, leaf area per plant $(70.3 \%)$, leaf area index $(74.1 \%)$, size of individual bulb $(42.2 \%)$, fresh weight of single bulb (44.5\%), number of storage leaves per bulb (13.8\%), plant dry weights (67.5\%) and dry bulb yield (58.8\%). The next is Bashiqi cultivar which was significantly exceeded Local White cultivar in plant height $(24.9 \%)$, leaf area per plant $(147 \%)$, percentage of unbolted plants $(43.4 \%)$, leaf water saturation deficit $(23.7 \%)$, bulbing ratio $75 \%$ ) and dry matter percentage of storage leaf $(9.6 \%)$. Local White cultivar substantially exceeded its corresponding cultivars in bulb bulk density and tss. However, it significantly increased the stalk numbers per plant, fresh and dry weight of stalks in comparison to other cultivars (Table,4a). Local Red appeared to be the superior cultivar in all experiments, it displayed the highest drought resistance ability plus its highest responses to mulching and supplemental watering in relation to other cultivars. The superiority of this cultivar might be attributed to its gene expressing abilities to sustain the highest value of parameters favored for best growth and yield and the lowest values in parameters not favored for optimal growth and yield under such sub optimal circumstances. These results are in favor with those obtained by Abdel (1995).

Irrigation and mulching interactions results revealed that supplementary irrigated onion raised on clear polyethylene mulched soil gave significantly higher leaf number per plant (10.4), leaf area index (0.4), leaf water potential ($0.42 \mathrm{Mpa})$, bulbing ratio $(0.25)$, fresh weight of bulb $(84.3 \mathrm{~g})$, size of single bulb (88.2 cm3), bulb bulk density (0.95 g.m-3), number of storage leaves (10.9) and plant dry weight $(0.14 \mathrm{~kg} \cdot \mathrm{m}-2)$. Followed by complementary irrigated onion grown on black polyethylene mulched soil which manifested the highest plant height $(49 \mathrm{~cm})$, leaf area per plant $(450.5 \mathrm{~cm} 2)$ and yield of dry bulb $(0.83 \mathrm{~kg} \cdot \mathrm{m}-2)$. On the other hand non-irrigated onions of bare soils gave the lowest plant height $(39.6 \mathrm{~cm})$, leaf area index $(0.18)$, leaf water potential (-0.84 Mpa), bulbing ratio 0.19), fresh weight of bulb (30 g), bulb bulk density (0.91 g.cm-3), storage leaf dry matter percentage (15.3\%), plant dry weights $(0.04 \mathrm{~kg} . \mathrm{m}-2)$ and dry bulb yield $(0.25 \mathrm{~kg} . \mathrm{m}-2)$. When a comparison was made between supplementary irrigated onion grown on bare soil which is adapted by onion growers and non-irrigated onion grown on polyethylene mulched soil, compelling results were found suggested that polyethylene mulching ensure the successfulness of producing onion of reasonable quality under rain fed. This finding was inferred from the obtained non-significant differences detected between these two treatments. These results are agreed with those reported by Abdel (1990) and Al-Juboori (2005).

Irrigation and cultivar interactions revealed that Local Red under both watered and rain fed cultivations was the superior cultivar over others. Under complementary watering, this cultivar gave the highest plant height $(52 \mathrm{~cm})$, leaf numbers per plant (11), leaf area per plant $(635.7 \mathrm{~cm}-2)$, leaf area index (0.57), percentage of unbolted plants $(84.1 \%)$, fresh weight of single bulb (96.9 g), bulb size (101.4 cm3), storage leaf numbers per bulb (11.7), storage leaf dry matter percentage $(18.9 \%)$, plant dry weights $(0.2 \mathrm{~kg} . \mathrm{m}-2)$ and bulb dry yield 
(1.08 kg.m-2).Under rainfalls Local Red also displayed the highest plant height $(47 \mathrm{~cm})$, leaf numbers per plant $(9.8)$, leaf area per plant $(416.3 \mathrm{~cm} 2)$, leaf area index (0.37), leaf water potential $(-1 \mathrm{Mpa})$, percentage of unbolted plants $(84.8 \%)$, number of storage leaf per bulb(9.8), plant dry weights $(0.1 \mathrm{~kg} . \mathrm{m}-2)$ and yield of dry bulb (0.66 kg.m-2). Irrigated Bashiqi treatments showed the highest bulbing ratio (0.26) and stalk fresh weights $(89$ g.m-2).Whereas, under rainfalls, this cultivar prevailed in bulbing ratio (0.25) and tss (16.9\%). Irrigated Local White cultivar gave the highest numbers of stalk per plant (107), stalk dry weights (12 g.m-2) and bulb doubling percentage (78.6\%). While, under rainfalls, this cultivar significantly exceeded others in stalk numbers per plant (1.8), stalk fresh weights (84.7 g.m-2), and bulb doubling percentage (45.9\%). Similar results were achieved by Abdel (1991).

Mulching and cultivars interactions displayed that Local Red grown on clear polyethylene mulched soil significantly exceeded Local White grown on bare soil in leaf number per plant $(37.5 \%)$, leaf area per plant $(281.3 \%)$, leaf area index (271.4\%), bulbing ratio (166.7\%), and weight of single bulb (128.8\%). However, it gave the lowest leaf water saturation deficit, fresh and dry weight of stalks (Table,2b). From these results we may inferred that there are apparent differences among tested cultivars in their responses to mulching , no doubt the best responded cultivar is Local Red.

Irrigation, mulching and cultivars interactions (Table2) revealed that supplementary irrigated Local Red cultivar grown on clear polyethylene mulched soil treatment highly exceeded treatment of non-irrigated Local White of bare soil in bulb size $(139.5 \%)$, storage leaf numbers per bulb (950\%), plant dry weights $(151.3 \%)$ and dry bulb yield $(130.5 \%)$. The results confirmed that Local Red cultivar is the most drought resistance cultivar, and Local White is a drought susceptible cultivar, while, Bashiqi occupied the gap between the two cultivars. Results also prevailed the impossibility of producing a reasonable onion yield under rainfall incidences in Mosul without the aid of polyethylene mulching. These findings were inferred from the observed significant differences between non-irrigated onions of mulched and unmulched treatments. Similar conclusions were drawn from previous investigations in Mosul ( Abdel, 1990 and Al-Juboori, 2005).

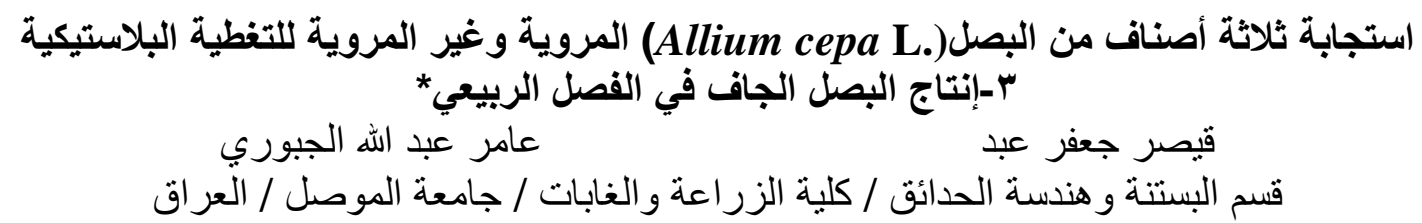

الخلاصة

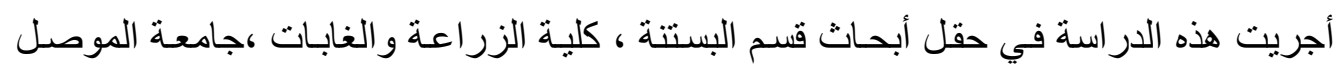

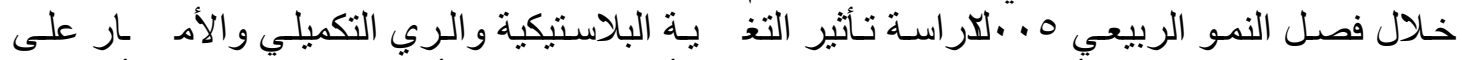

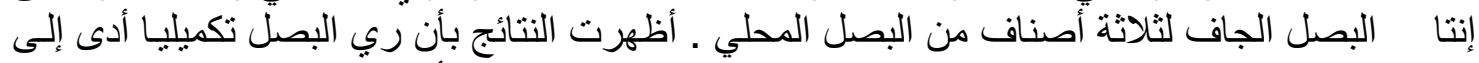

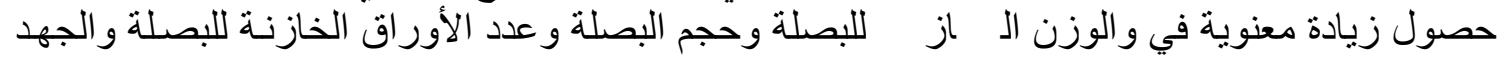

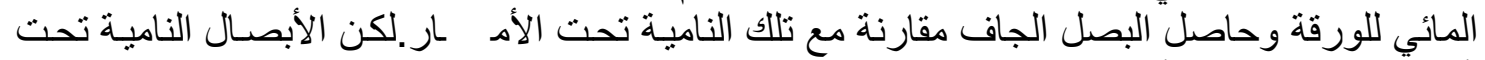

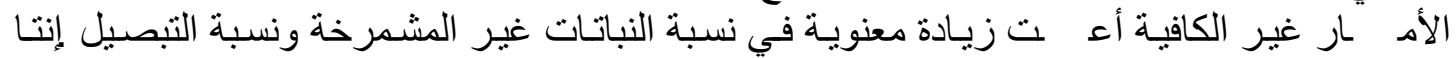




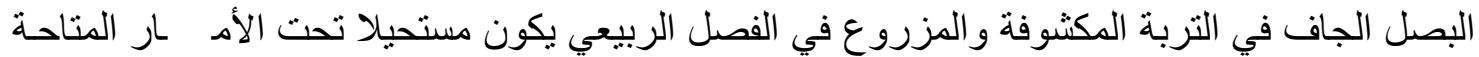

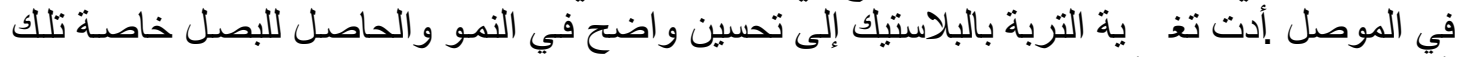

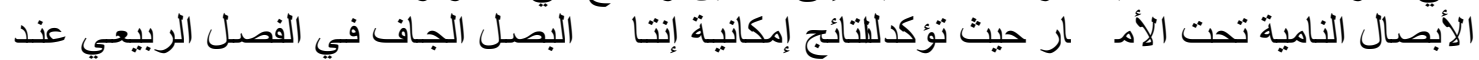

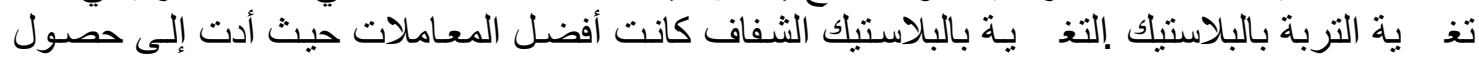

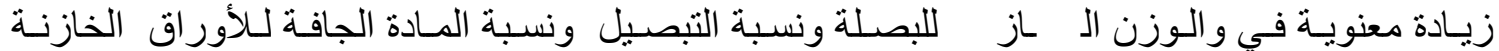

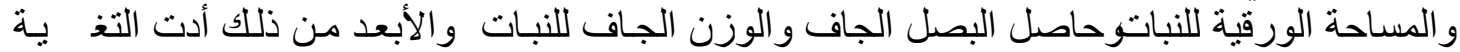

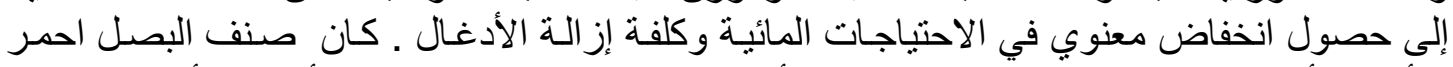

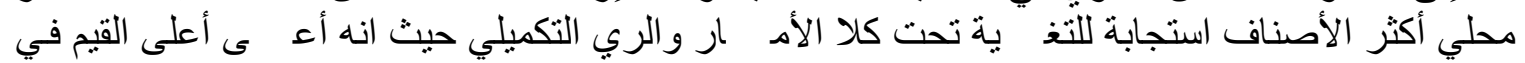

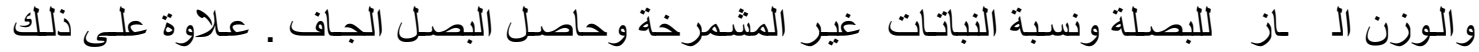

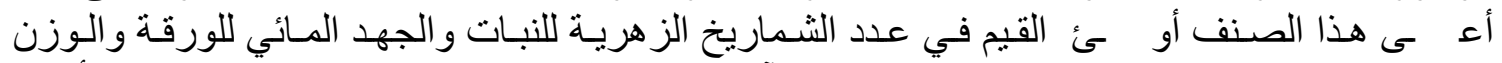

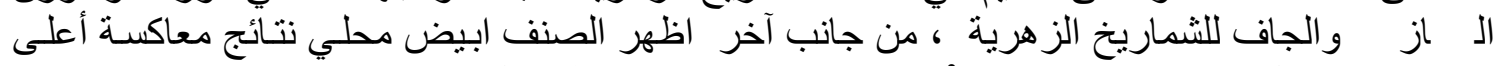

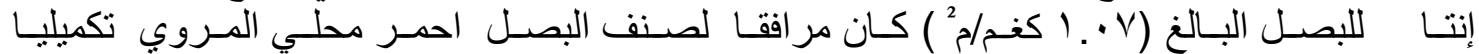

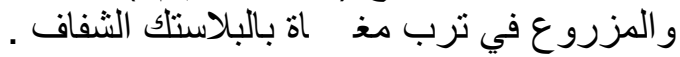

تم تمويل هذا المشروع مـن قبل AHEAD ، مشروع اتفـاق التعـاون بين جامعـات هـاواي والموصل ودهوك 


\section{REFERENCES}

Abdel, C. G., (1982). Drought resistance in (Vicia faba L.): A study of four cultivars. MSc thesis, Bath University, Bath, England, UK.

Abdel, (1990). The influence of mulching on irrigated and non-irrigated onion cultivations. Mesopotamia J. of Agric. 22 (4).

Abdel, C. G. (1995). Effects of supplementary irrigation and Indole-3-butyric acid on onion growth and yield. Mesopotamia, J. of Agric. 27 (1).

Al-Jamal, M. S.; S. Ball and T. W. Sammis, (2001). Comparison of sprinkler, Trickle and Furrow irrigation efficiencies for onion production. Agricultural Water Management 46: 253-266.

Al-Jamal, M. S.; T. W. Sammis; S. Ball and D. Smeal (1999). Yield-based irrigation onion crop coefficients. Amer. Soc of Agric. Eng. 15 (16): 659668.

Al-Juboori, A. A. H. (2005). The possibility of onion cultivation under different polyethylene mulching with the use of supplemental irrigation and rainfalls. MSc thesis, Mosul University, Mosul, Iraq.

Brewester, J. L. (1979). The response of growth rate to temperature of seedlings of several Allium crop species. Annals of Applied Biology. 93, 351-357.

Clark,G. A.; E. E. Albrequts; C. D. Stanly; A. G. Smajastral and F. S. Zazucta (1996). Water requirement and crop coefficients of drip-irrigated strawberry plants. Transaction of ASAE, 39, 905-913.

Faysal, M. S.(1999). Rapid field method for the estimation of leaf area of onion grown under supplemental watering and drought. Mesopotamia J. 31(4): 26-29.

Greer, L. and G. Kuepper (1999). Organic Allium production. ATTRA. Horticulture production guide. 800-346-9140. pp20.

Kelley, W. T. and D. M. Granberry (2000). Commercial vegetable, productions: dry bulb onions. Cooperative extension services. Pp14.

Mississippi (2002). Commercial production of bulb onions in Mississippi State University, Extension service. Pp4.

Paris, P.; G. Olempieri; L. Todaro; A. Pisanelli and F. Cannata (1998). Leaf water potential and soil water depletion of walnut mulched with polyethylene and intercropped with alfalfa in central Italy. Agroforestry system, 40: 68-81.

Shock, C. C. ;E. B. G. Fribert and L. D. Saunders (1998). Onion varieties graded out of storage. Malheur Experiment Station. Oregon State University. Pp9. Internet.

Singh, S. P. (1992). Studies on mulching of vegetable crops- a review advances in horticulture and forestry. 2: 115-143.

Stapleton, J. J. (1993). Establishment of Apricot and Almond trees using soil mulching with transparent and black poly ethylene film: Effects of verticillium wilt and tree health. Plant Pathology. 42: 333-338.

Spomer, L. A. (1985). Techniques for measuring plant water. Hortscience. 20 (6): P 21-27. 
Stasoviski, E. and C. A. Peterson (1992). Effects of drought and subsequent rehydration on the structure, vitality and permeability of ( Allium cepa, L.) adventitious roots. Can. J. Bot. 71: 700-707.

Streck, N. A. ; F. M. Schneider and G. A. Buriol (1996).Soil heating by solarization inside plastic greenhouse in Santa Maria, Rio Grande de sul, Brazil. Agriculture Forest Meteorology. 82: 73-82.

Vavrina, C. S. and D. A. Smittle (1993). Evaluating sweet onion cultivars for sugar concentration and pungency. HortScience 28: 804-806.

Wien, H. C. (1997). The Physiology of Vegetable Crops. CAB International Pub.

Whalley, W. R. ; W. E. Finch-Savage ; R. E. Cope; H. R. Rowse and N. A. R. Bird (1999). The response of carrot (Daucus carota, L.). and onion (Allium cepa, L.). seedlings to mechanical impedance and water stress at sub-optimal temperatures. Plant, Cell and Environments. 22: 229-211. 